\title{
THE
}

6-1-2019

\section{Comparing the Efficiency of Nursery and Direct Transplanting Methods for Restoring Endangered Corals}

\author{
Graham E. Forrester \\ University of Rhode Island, gforrester@uri.edu \\ Maggie Chan \\ Dennis Conetta \\ Russell Dauksis \\ Katie Nickles
}

See next page for additional authors

Follow this and additional works at: https://digitalcommons.uri.edu/nrs_facpubs

The University of Rhode Island Faculty have made this article openly available.

Please let us know how Open Access to this research benefits you.

This is a pre-publication author manuscript of the final, published article.

Terms of Use

This article is made available under the terms and conditions applicable towards Open Access Policy Articles, as set forth in our Terms of Use.

\section{Citation/Publisher Attribution}

Forrester, G.E., Chan, M., Conetta, D., Dauksis, R., Nickles, K., \& Siravo, A. (2019). Comparing the Efficiency of Nursery and Direct Transplanting Methods for Restoring Endangered Corals. Ecological Restoration 37(2), 81-89. http://er.uwpress.org/content/37/2/81.abstract.

This Article is brought to you for free and open access by the Natural Resources Science at DigitalCommons@URI. It has been accepted for inclusion in Natural Resources Science Faculty Publications by an authorized administrator of DigitalCommons@URI. For more information, please contact digitalcommons-group@uri.edu. 
Authors

Graham E. Forrester, Maggie Chan, Dennis Conetta, Russell Dauksis, Katie Nickles, and Alicia Siravo

This article is available at DigitalCommons@URI: https://digitalcommons.uri.edu/nrs_facpubs/179 
2 Comparing the Efficiency of Nursery and Direct Transplanting Methods for Restoring

\section{Endangered Corals}

5 Graham E. Forrester, Maggie Chan, Dennis Conetta, Russell Dauksis, Katie Nickles and Alicia

6 Siravo

8 Abstract

9 Restoration of plants, corals, and other sessile species often involves transplanting individuals to sites

10 chosen for rehabilitation. Transplanted individuals are sometimes harvested directly from wild

11 populations (direct transplanting), and sometimes propagated or cultured in a "nursery" before being

12 transplanted (nursery outplanting). The ecological effectiveness and cost-efficiency of these methods

13 have rarely been compared, so we performed an experiment to address this. Coral fragments,

14 Acropora cervicornis $(\mathrm{n}=780)$, were collected and assigned to one of three treatments: 1$)$ directly

15 transplanted to a restoration site and placed loose on the reef; 2) directly transplanted and manually

16 attached to the reef; 3) moved to a nursery site near the restoration site for three months before being

17 transplanted and manually attached to the reef. Treatment 1 was inefficient simply because these

18 corals survived poorly. After 15 months, the survival and growth of corals assigned to treatments 2

19 and 3 was similar. The nursery method (3) was more expensive and time-consuming than direct

20 transplanting (2), so treatment 2 yielded twice as many surviving corals per hr of work invested and

21 three times as many survivors per dollar of set-up costs as treatment 3 . The net production of live

22 coral tissue per hr or per dollar invested was also greatest for direct-attached transplants. Cost- and 
23 time-efficiency are important considerations for practitioners seeking to maximize the area of reef

24 rehabilitated and, in this case study, were maximized by bypassing a nursery stage.

25 Keywords: Acropora, cost-benefit, growth, staghorn coral, survival, tissue production

\section{Restoration Recap}

28 - We present a case study using the coral Acropora cervicornis that uses the money and time

29 required to restore populations as a simple way to compare the efficiency of alternate restoration

30 methods.

31 - Transplanting fragments without affixing them to the reef was the simplest and cheapest method,

32 but poor fragment survival made this method inefficient.

33 - The growth and survival of directly transplanted fragments that were affixed to the reef was

34 similar to that of fragments that spent three months in a nursery before transplanting. However,

35 because the nursery took extra time and money to set up, it was less efficient than direct

36 transplanting.

37 - Because cost- and time-efficiency calculations may be specific to species, location, and

38 procedural detail, further tests are needed to generalize about methodological efficiency.

39 Practitioners are thus encouraged to weigh the costs and benefits of different protocols on a case-

$40 \quad$ by-case basis.

42 Despite the fact that time and money for restoration is limited, there have been relatively few

43 comparative analyses of the cost-effectiveness of restoration protocols (Benayas et al. 2009, Aronson

44 et al. 2010, de Groot et al. 2013). Such analyses are of particular value for corals, which are the

45 foundation species for the most biologically diverse marine ecosystem, yet have been in decline 
globally for the past 40 years (De'ath et al. 2012, Jackson et al. 2014). In response to coral declines,

47 coral restoration has grown rapidly in popularity and is now practiced worldwide by many non-profit

48 groups and government agencies, but a global analysis suggests that coral reefs are the most

49 expensive ecosystem to restore per unit-area (de Groot et al. 2013, Bayraktarov et al. 2016).

50 Restoration of sessile foundation species such as trees, seagrasses, mangroves, and corals

51 often involves transplanting individuals to degraded sites (e.g., Putz et al. 2001, Rinkevich 2005,

52 Lewis 2009, Paling et al. 2009). Transplanted individuals are usually small and may include seeds or

53 propagules, juveniles, cuttings, and asexual fragments. We used asexual coral fragments derived from

54 adults in wild populations, the most widely used approach for coral restoration projects (Rinkevich

55 2005, Precht 2006, Edwards and Gomez 2007, Edwards 2010, Johnson et al. 2011, Young et al. 2012,

56 Chavanich et al. 2014). Protocols for transplanting fragments can be classified into those which: 1)

57 transplant individuals harvested directly from wild populations (hereafter direct transplanting); or 2)

58 culture wild fragments in a "nursery" for some time before transplanting (hereafter nursery-

59 outplanting).

60 We compared the time- and cost-effectiveness of two direct transplanting approaches, referred

61 to as "direct-loose" and "direct-attached" methods respectively. In the direct-loose approach,

62 fragments are simply placed on the substratum at the restoration site (e.g., Bowden-Kerby 1997,

63 Lindahl 1998, Bowden-Kerby 2001, Lindahl 2003). This approach mimics the fate of asexual

64 fragments generated by storms or broken from parent colonies by human activity (e.g., Fong and

65 Lirman 1995, Smith and Hughes 1999). Tissue growth occasionally re-attaches these fragments to the

66 substratum, in which case they may form a new colony (e.g., Tunnicliffe 1981). Although past

67 research shows the survival of direct-loose transplants can be poor (e.g., Bak and Criens 1981,

68 Knowlton et al. 1981, Mercado-Molina et al. 2014), this method has been used in several restoration

69 projects (e.g., Lindahl 1998, 2003) and its relative simplicity makes it a useful benchmark against 
70 which to evaluate more elaborate and expensive methods. More common, however, is the direct-

71 attached method wherein transplanted coral fragments are manually secured to the substratum.

72 Securing fragments increases the probability that they will subsequently grow to self-attach to the

73 reef (e.g., Guest et al. 2011) and so improves their long-term survival (e.g., Forrester 2011, Forrester

74 et al. 2014), but the benefit of this improved survival has rarely been weighed against the increased

75 time and money required (Edwards et al. 2010).

76 We also compared direct transplants to nursery outplants. Nursery outplanting has been

77 widely adopted, and typically involves the culturing fragments in sheltered inshore nursery sites away

78 from reefs (Epstein et al. 2003, Rinkevich 2005). Nursery cultivation usually involves constructing

79 structures to hold or suspend the coral fragments, plus regular cleaning and maintenance of the

80 nursery apparatus, so almost certainly requires a greater investment of time and money per coral than

81 direct transplanting. Nurseries have been advocated for multiple reasons (Rinkevich 2005, 2014), but

82 we evaluated only their hypothesized benefits for fragment growth and survival. These benefits are

83 predicted because fragments in nurseries can be positioned for exposure to favorable flow and

84 lighting conditions, and isolated from the harmful effects of sediment, competitors, predators, and

85 pathogens present on the reef (Epstein et al. 2003). Direct comparisons among these protocols are

86 limited (for an exception see dela Cruz et al. 2015), so our objective was to quantify the cost- and

87 time-efficiency of the two methods to test whether the expected higher survival of nursery outplants

88 offsets the increased costs of cultivation.

\section{Methods}

\section{$90 \quad$ Study Species}

91 We studied staghorn corals, Acropora cervicornis (Lamarck, 1816), formerly a major reef-building

92 coral in Caribbean at intermediate depths $(5-15 \mathrm{~m})$. This species suffered a particularly acute decline 
93 region-wide since the 1980s (Jackson et al. 2014), which prompted its listing under the US

94 endangered species act, the IUCN red list, and CITEs Appendix II (National Marine Fisheries Service

95 2006). Fragmentation and reattachment is an important mechanism of asexual reproduction for this,

96 and other branching coral species (Highsmith 1982). Fragments are generated naturally by storms,

97 unintentionally when boats and people collide with reef, and deliberately when colonies are pruned

98 for restoration (Johnson et al. 2011, Young et al. 2012). Fragments generated from each of these

99 sources grow quickly and have been used for both direct transplanting and nursery outplanting

100 (Johnson et al. 2011, Young et al. 2012). Acropora cervicornis is the species most commonly used

101 species for reef restoration in the Caribbean (Young et al. 2012, Schopmeyer et al. 2017), and

102 Acropora is the most widely used genus for restoration globally (Edwards and Gomez 2007,

103 Rinkevich 2014).

\section{Source and Restoration Sites}

105 To increase generality of the outcome, we used two study sites, Harris Ghut (HG) and Muskmelon

106 Bay (MB), both of which were near Guana Island, British Virgin Islands: (Figure S1). MB was

107 roughly $420 \mathrm{~m}^{2}$ in area and HG was roughly $800 \mathrm{~m}^{2}$. Both sites are wave-protected fringing reefs,

108 close to horizontal in profile, with relatively low rugosity (1.6-1.9 based on the chain method

109 ([Alvarez-Filip et al. 2009]) and low total coral cover (5-10\%). Although A. cervicornis is now rare

110 on both reefs $(<0.2 \%$ cover $)$, their depth $(5-7 \mathrm{~m})$ and leeward location (Goreau 1959, Bak 1977), plus

111 local eyewitness accounts from the 1980s, suggest they are suitable habitat. We collected 780

112 "fragments of opportunity" for the study (Johnson et al. 2011, Young et al. 2012). Fragments were

113 sourced from two leeward reefs (2-7 m deep) that were 2-4 km from the restoration sites and support

114 recovering A. cervicornis populations (Figure S1). Fragments were collected on snorkel, placed in

115 bins of seawater on a boat, and then taken directly to the restoration sites. At the restoration site, 
116 fragments were placed temporarily on the reef for 1-6 days, after which they were assigned to one of

117 the treatments to start the experiment (start dates ranged from 13-19 Aug 2013). Although variable,

118 time between transport and the start of the experiment was equal among treatments so it did not affect

119 the outcome.

120 Experimental Design

121 Fragments were randomly assigned to one of three treatments (Figure S2): 1) Direct-loose transplants

$122(\mathrm{n}=138$ at $\mathrm{HG}, \mathrm{n}=45$ at MB); 2) Direct-attached transplants $(\mathrm{n}=225$ at $\mathrm{HG}, \mathrm{n}=81$ at $\mathrm{MB})$; and 3)

123 Nursery-outplants $(\mathrm{n}=183$ at $\mathrm{HG}, \mathrm{n}=108$ at MB).

124 In August, we constructed three line nurseries at MB and four at HG (see Johnson et al. 2011,

125 Griffin et al. 2012). Nurseries were placed in sandy protected areas, 7-10 $\mathrm{m}$ deep, 25-40 m inshore

126 from each restoration reef (Figure S3). Each nursery consisted of a rigid outer PVC frame (2m x $2 \mathrm{~m}$

127 or $2 \mathrm{~m} \times 3 \mathrm{~m}$ ), from which we strung rows of monofilament line spaced $25-\mathrm{cm}$ apart. The nursery-

128 outplant fragments were hung from the monofilament at $25-\mathrm{cm}$ intervals using plastic-coated wire

129 (Figure S4). Each nursery was anchored using concrete blocks and suspended vertically using

130 subsurface buoys so that the corals were 5-7 m deep. Nurseries were not maintained after set-up, but

131 there was no obvious subsequent overgrowth by fouling organisms.

132 In August, we placed the direct-loose fragments on the reef, and the direct-attached fragments

133 were secured to the reef using cable ties (see Garrison and Ward 2008) tied to masonry nail anchors

134 (see Lirman et al. 2014). Twelve weeks later (24-27 October 2014), the nursery-outplants were

135 removed from the nursery and secured to the reef using cable ties. We ensured that fragments from

136 different treatments were interspersed at each site, and were at roughly equal densities (all fragments

137 were $\geq 40 \mathrm{~cm}$ apart). When corals from all treatments were first moved to the reef, we photographed

138 them, mapped their location and secured a numbered identification tag to the reef nearby (Figure S2) 
139 (Forrester 2011). We monitored the survival and growth of the coral fragments after 12 weeks (26-29

140 October 2013), after 24 weeks (19-21 January 2014) and after 64 weeks (26-28 October 2014).

141 Acropora cervicornis fragments can grow to form a tissue connection with the reef within 8 weeks of

142 transplanting (e.g., Bowden-Kerby 2001), so corals from all treatments had time to self-attach to the

143 reef and experience ecological conditions on the reef (Guest et al. 2011, Forrester et al. 2014).

144 Because direct-loose fragments were not attached to the substratum, they could potentially be

145 moved by currents. To track their survival, we thus searched the entire site and the area within $5 \mathrm{~m}$ of

146 the perimeter in case fragments had been moved out of the site. Each time the fragments were

147 monitored, we took several photographs of each fragment encountered and, using the maps and

148 previous photographs, we attempted to identify each loose fragment based on its location and

149 appearance. Relatively few fragments disappeared during the study (direct-loose: $\mathrm{n}=10$, direct-

150 attached: $\mathrm{n}=3$, nursery-outplants, $\mathrm{n}=2$ ). When calculating survival, corals that disappeared were

151 assumed to have died.

\section{Measuring Fragment Survival}

153 We compared the survival of fragments between treatments and sites using the non-parametric

154 Kaplan-Meier survival model (Lee 1992, Kleinbaum and Klein 2011). Because periodic monitoring

155 yields a record of whether a coral is alive on each census date, estimates of survival time were thus

156 either interval-censored (when a fragment died between two censuses) or right-censored (when the

157 fragment was still alive at the end of the study) (Lee 1992). Separate survival curves were fit for each

158 treatment $\times$ site combination, and the survival parameters were judged different if their $95 \%$

159 confidence intervals did not overlap. 
161 Acropora cervicornis colonies are composed of cylindrical branches whose diameter varies much less

162 than their length, so we summed the length of all branches, excluding areas of dead tissue, as a simple

163 estimate of colony size (hereafter TLD, see Figure 5 and Shinn (1966)). To assess colony growth, we

164 compared the mean TLD of surviving colonies among treatments (a fixed effect) and sites (a random

165 effect) at the start and end of the experiment using a two-factor analysis of variance (ANOVA). The

166 ANOVA model included the two main effects and their interaction. Before conducting the analyses,

167 we checked whether the data met the assumptions of ANOVA (TLD data at the end of the experiment

168 were heteroscedastic and so were $\log _{10}$ transformed to meet the assumption of equal variances).

169 To assess how much new live tissue was produced per coral, we also calculated net tissue

170 production over the course of the study $\left(\mathrm{TLD}_{\text {final }} / \mathrm{TLD}_{\text {initial }}\right)$. To measure TLD divers took photographs

171 of each coral from different angles to capture images of each branch, with a ruler in the frame to

172 provide a scale. We later used image analysis software (ImageJ) to measure each branch (Abramoff et

173 al. 2004). To check of the accuracy of the photographic method, divers also measured a subset of the

174 corals $(n=102)$ in the field using a flexible tape measure (Figure S6). There was a close relationship

175 between the direct field (x) and photographic $(\mathrm{y})$ TLD measurements (linear regression: $(\mathrm{n}=102$,

176 range of $\left.\mathrm{TLD}=2-173 \mathrm{~cm}, \mathrm{y}=5.51+0.78 \mathrm{x}, \mathrm{r}^{2}=0.91\right)$, suggesting that measurement error did not

177 obscure differences between treatments (Figure 2) (Kiel et al. 2012).

178 Quantifying the Outcome of the Restoration in Terms of Time and Cost Invested

179 To evaluate the time and cost-efficiency of the three restoration methods, the time needed to establish 180 each coral on the reef was quantified (hrs per coral; Table S1). We logged each step of the restoration 181 process at the field site (Table S1), but excluded accessory tasks such as washing SCUBA gear and 
182 filling tanks. Time to complete tasks common to all methods, such as searching donor sites for

183 fragments, was divided according to the number of corals involved per treatment.

184 We also calculated the local purchase price of materials needed to establish each coral at the

185 restoration site in US\$ per fragment, which included materials for attaching corals to the reef and

186 materials for the nursery frames (Table S2). We excluded some costs that were common to all

187 methods (e.g., SCUBA and snorkel equipment for participants, and bins to hold fragments while

188 being transported in the boat), and others that are context- and location-specific (e.g., air travel to the

189 project site, food, and accommodation costs) (Edwards et al. 2010). We also excluded the time and

190 cost invested in the scientific monitoring such as attaching tags, measuring, and photographing corals

191 because this is not essential for practical restoration projects.

192 We then calculated coral survival and tissue production as a function of the time invested and

193 money spent on materials. To measure return on time invested, we calculated the number of surviving

194 corals at the end of the study that were produced per hr of initial set-up time (survivors after 64 weeks

195 per hr). We also calculated the net production of coral (TLD final $/$ TLD $\left._{\text {initial }}\right)$ per hr of initial set-up time.

196 To measure return based on financial cost, we calculated the number of surviving corals at the end of

197 the study that were produced per dollar of materials (survivors after 64 weeks per US\$) and net coral

198 production $\left(\mathrm{TLD}_{\text {final }} / \mathrm{TLD}_{\text {initial }}\right)$ per dollar of materials.

\section{Results}

200 Survival

201 At both sites, survival of loose fragments was significantly lower than that of nursery and directly

202 attached fragments by the end of the study (Figure 1 and Figure S7). Survival of corals from the latter

203 two treatments was site-dependent (Figure S7). In Harris Ghut, nursery fragments survived

204 significantly better than directly attached fragments while suspended on the nursery frames, but this 
205 initial advantage was subsequently overturned and, at the end of the experiment, survival did not

206 differ between the two treatments (Figure S7). In Muskmelon Bay, however, the survival of nursery

207 outplants was significantly lower than that of directly attached fragments throughout (Figure S7).

208 Pooling sites to give a project-wide overview revealed no overall difference in the survival of direct-

209 attached fragments and nursery-outplants (Figure 1).

\section{Growth of Surviving Fragments}

211 At the start of the experiment, fragments did not differ in size among treatments or sites (ANOVA: $p$

$212>0.05$ for main effects and interaction term; Figure 1 and Figure S8). At the end of the experiment,

213 however, direct outplants at Muskmelon Bay had grown significantly larger than all other groups of

214 fragments (ANOVA: treatment $\times$ site interaction; $F_{2,300}=4.18, p=0.016$; Fig. S9). Although the

215 differences between restoration treatments were site-specific, pooling sites to give a study-wide

216 overview revealed that direct-attached fragments generally reached larger sizes than nursery-outplants

217 and direct-loose fragments (Figure 2).

\section{Return on Investment}

219 Even though directly transplanted loose fragments took little time to place on the bottom, the fact that

220 they survived so poorly meant that there were few survivors and very little return on investment

221 (Figures 3 and 4). For the remaining two treatments, survival was similar but nursery-outplants

222 received a greater investment of time and money per coral than direct-attached fragments.

223 Consequently, direct transplanting produced roughly twice as many surviving corals per hr invested,

224 and three times as many survivors per dollar, as the nursery treatment (Figure 3). Because direct-

225 transplants grew slightly faster than nursery-outplants, the differential in return on investment was

226 magnified further when expressed as net tissue production (Figure 4). 


\section{Discussion}

228 The poor survival of loose transplants is consistent with most previous studies of loose fragments

229 (e.g., Bowden-Kerby 1997, Lindahl 1998, Smith and Hughes 1999, Bowden-Kerby 2001, Forrester

230 2011), suggesting that this method would only become efficient if fragments were extremely plentiful

231 and securing fragments to the reef was very expensive and time-consuming. Because hurricane

232 damage to branching corals can create enormous numbers of fragments, most of which die in the

233 subsequent months (e.g., Knowlton et al. 1981), the immediate aftermath of a major storm might

234 create a situation favoring this method. Other agents of extensive local damage, such as a major boat

235 grounding, might also create conditions for this method to be cost- and time-efficient.

236 Because nursery outplants and direct-attached transplants had similar survival, our results did

237 not support the hypothesis that time in a nursery improves the subsequent survival of transplanted

238 corals (Epstein et al. 2003). Broadly similar findings were reported in the only other direct

239 comparison of these methods we know of (dela Cruz et al. 2015). While in nurseries, fragments of

240 two non-branching Pacific corals survived better than equivalent direct transplants, but this advantage

241 dissipated when corals from the nursery were then placed on the reef alongside direct outplants (dela

242 Cruz et al. 2015).

Although the overall survival of nursery outplants and direct-attached transplants was similar

244 in our study, we did observe differences between the two treatments in apparent causes of death. A

245 macroalgal bloom (Dictyota spp.) coincident with the start of the study appeared to smother many

246 direct transplants but had no effect on fragments while they were in the nursery, which supports the

247 hypothesis that being on the reef places direct-transplants at risk from negative species interactions

248 (Forrester et al. 2012, Johnston and Miller 2014, Miller et al. 2014, Casey et al. 2015). Both groups of

249 corals were vulnerable to human impacts, but from different activities. In Muskmelon Bay, some 
250 direct-transplants were apparently killed by boat anchoring, while some nursery corals died as a result

251 of physical damage to the nursery frames (we believe the frames were damaged inadvertently by

252 fishing nets). Future studies are needed to test whether other agents of coral mortality differentially

253 impact nursery outplants and direct transplants. Both groups are vulnerable to storms, predators,

254 climate-induced bleaching events, and disease epidemics (e.g., Garrison and Ward 2008, Shaish et al.

255 2010a, b, Forrester et al. 2014), and more direct comparisons are needed to quantify their relative

256 importance and quantitative effects.

257 We also found that the costs of restoration differed among the three methods tested. A cross-

258 ecosystem comparison revealed that coral reefs are typically the most expensive habitat to restore per

259 unit area (de Groot et al. 2013, Bayraktarov et al. 2016), which raises the concern that high costs will

260 limit all coral restoration projects to rehabilitating tiny areas relative to the vast swaths of degraded

261 reef (Mumby and Steneck 2008). For that reason, all three methods we selected for comparison were

262 relatively simple and inexpensive because we assumed low-cost protocols may be more readily

263 adopted by non-specialists and scaled-up to restore large areas of reef. Although material costs are

264 rarely quantified, other materials that have been used to stabilize transplanted corals and construct

265 nurseries appear to vary widely in cost (Bayraktarov et al. 2016). For example, the cable ties and nails

266 we used to affix corals to the reef are similar to string and wire in having a relatively low cost per-

267 coral, whereas other frequently used alternatives such as epoxy and hydrostatic cement are more

268 expensive. Likewise, the pvc and fishing line we used to construct nursery frames is likely cheaper

269 than some other options, such as epoxy-coated rebar.

Perhaps the most important decision we made to reduce costs was to keep corals in the

271 nursery for a short time and perform no maintenance. An abridged nursery phase has been tested

272 occasionally (dela Cruz et al. 2015), but the most studies have kept corals in the nursery far longer,

273 regularly cleaned the nursery apparatus, removed encroaching predators, excised diseased tissue, and 
274 even provided supplemental feeding (Rinkevich 2005, Precht 2006, Edwards and Gomez 2007,

275 Edwards 2010, Johnson et al. 2011, Young et al. 2012, e.g., Chavanich et al. 2014, Toh et al. 2014).

276 Additional explicit comparisons between methods are thus needed to test if our preference for

277 simplicity was justified, or whether the greater expense and labor requirements of these more

278 elaborate and extended nursery methods are outweighed by substantial improvements in coral

279 survival and tissue production.

280 Our analysis represents a simple and partial assessment of the costs and benefits of

281 restoration. We compared costs based on the direct investments of time and money necessary to set-

282 up and maintain a project because these costs are important for practitioners and non-profit groups to

283 consider when allocating their limited resources (de Groot et al. 2013). The assessment of project

284 costs could be expanded to include other costs, such as damage to the donor site (though we suggest

285 this cost was negligible in our study) and the opportunity cost from benefits forgone in the absence of

286 restoration (Spurgeon 2001, de Groot et al. 2013). There is also scope for improvement in our

287 analysis of the benefits of restoration. Like most previous analyses, the benefit of our restoration was

288 measured based only on the demography of the transplanted coral species (Rinkevich 2005, Precht

289 2006, Edwards 2010, Johnson et al. 2011, Young et al. 2012, Schopmeyer et al. 2017). While

290 comparing unit benefits per coral after a semi-arbitrary endpoint is a reasonable starting point

291 (Edwards et al. 2010), and can be expanded in innovative ways (Rinkevich 2015), we urgently need

292 longer-term assessments of benefits based on how the entire ecological community responds to the

293 restoration (e.g., Cabaitan et al. 2008, Yap 2009, Merolla et al. 2013, dela Cruz et al. 2014). This

294 would allow use of well-established frameworks for the valuation of ecosystem services (Kumar

295 2010, ten Brink 2011), and so provide a more comprehensive measure of the monetary value of

296 restored reefs (de Groot et al. 2012, de Groot et al. 2013). 


\section{Acknowledgements}

299 Thanks to Patricia Baily, Allison Holevoet, Meagan Leppicello, and Samantha Musser for

300 contributions to fieldwork and measuring images, and to the staff on Guana Island who provided

301 valuable logistical support. We are grateful for financial support from the Falconwood Foundation,

302 Dive BVI, RI-EPSCoR's SURF Fellowship program, the University of Rhode Island's Coastal

303 Fellowship program, and the University of Alaska MESAS IGERT Program (NSF award 0801720).

304

305

306

\section{References}

Abramoff, M.D., P.J. Magelhaes and S.J. Ram. 2004. Image Processing with ImageJ. Biophotonics International 11:36-42.

Alvarez-Filip, L., N.K. Dulvy, J.A. Gill, I.M. Cote and A.R. Watkinson. 2009. Flattening of Caribbean coral reefs: region-wide declines in architectural complexity. Proceedings of the Royal Society B-Biological Sciences 276:3019-3025.

Aronson, J., J.N. Blignaut, S.J. Milton, D. Le Maitre, K.J. Esler, A. Limouzin, et al. 2010. Are Socioeconomic Benefits of Restoration Adequately Quantified? A Meta-analysis of Recent Papers (2000-2008) in Restoration Ecology and 12 Other Scientific Journals. Restoration Ecology 18:143-154.

Bak, R.P. and S.R. Criens. 1981. Survival after fragmentation of colonies of Madracis mirabilis, Acropora palmata and A. cervicornis (Scleractinia) and the subsequent impact of a coral disease. Proceedings of the 4th International Coral Reef Symposium (Manila) 2:221-227.

Bak, R.P.M. 1977. Coral Reefs and Their Zonation in Netherlands Antilles: Modern and Ancient Reefs. Pages 3-16 in S.H. Frost, M.P. Weiss and J.B. Saunders (eds), Reefs and Related Carbonates-Ecology and Sedimentology. American Association of Petroleum Geologists. 
321 Bayraktarov, E., M.I. Saunders, S. Abdullah, M. Mills, J. Beher, H.P. Possingham, et al. 2016. The cost and feasibility of marine coastal restoration. Ecological Applications 26:1055-1074.

323 Benayas, J.M.R., A.C. Newton, A. Diaz and J.M. Bullock. 2009. Enhancement of Biodiversity and Ecosystem Services by Ecological Restoration: A Meta-Analysis. Science 325:1121-1124.

325 Bowden-Kerby, A. 1997. Coral transplantation in sheltered habitats using unattached fragments and cultured colonies. Pages 2063-2068 in H.A. Lessios and I.G. Macintyre (eds), Proceedings of the 8th International Coral Reef Symposium. Smithsonian Tropical Research Institute.

Bowden-Kerby, A. 2001. Low-tech coral reef restoration methods modeled after natural fragmentation processes. Bulletin of Marine Science 69:915-931.

330 Cabaitan, P.C., E.D. Gomez and P.M. Alino. 2008. Effects of coral transplantation and giant clam restocking on the structure of fish communities on degraded patch reefs. Journal of Experimental Marine Biology and Ecology 357:85-98.

333 Casey, J.M., S.R. Connolly and T.D. Ainsworth. 2015. Coral transplantation triggers shift in microbiome and promotion of coral disease associated potential pathogens. Scientific Reports 5:11903.

Chavanich, S., E. Gomez, L. Chou, B. Goh, L.T. Tan, K. Tun, et al. 2014. Coral restoration techniques in the Western Pacific region. Bangkok, Thailand: United Nations Intergovernmental Oceanographic Sub-Commission for the Western Pacific. estimates of the value of ecosystems and their services in monetary units. Ecosystem Services

342 de Groot, R.S., J. Blignaut, S. van der Ploeg, J. Aronson, T. Elmqvist and J. Farley. 2013. Benefits of 343 Investing in Ecosystem Restoration. Conservation Biology 27:1286-1293. 
344 De'ath, G., K.E. Fabricius, H. Sweatman and M. Puotinen. 2012. The 27-year decline of coral cover on the Great Barrier Reef and its causes. Proceedings Of The National Academy Of Sciences Of The United States Of America 109:17995-17999.

347 dela Cruz, D.W., B. Rinkevich, E.D. Gomez and H.T. Yap. 2015. Assessing an abridged nursery 348 phase for slow growing corals used in coral restoration. Ecological Engineering 84:408-415.

349 dela Cruz, D.W., R.D. Villanueva and M.V.B. Baria. 2014. Community-based, low-tech method of $350 \quad$ restoring a lost thicket of Acropora corals. Ices Journal of Marine Science 71:1866-1875.

351 Edwards, A.J. 2010. Reef Rehabilitation Manual. St. Lucia, Queensland, Australia: Coral Reef Targeted Research \& Capacity Building for Management Program.

353 Edwards, A.J. and A.D. Gomez. 2007. Reef restoration concepts and guidelines: Making sensible management choices in the face of uncertainty. St. Lucia, Queensland, Australia: Coral Reef Targeted Research \& Capacity building for Management Programme.

356 Edwards, A.J., J. Guest, B. Rinkevich, M. Omori, K. Iwao, G. Levy, et al. 2010. Evaluating costs of restoration. Pages 113-128 in A.J. Edwards (ed), Reef Restoration Manual. St Lucia, Queensland, Australia: Coral Reef Targeted Research and Capacity Building for Management

360 Epstein, N., R.P.M. Bak and B. Rinkevich. 2003. Applying forest restoration principles to coral reef rehabilitation. Aquatic Conservation: Marine and Freshwater Ecosystems 13:387-395.

362 Fong, P. and D. Lirman. 1995. Hurricanes cause population expansion of the branching coral 363 Acropora palmata (Scleractinia): Wound healing and growth patterns of asexual recruits. $364 \quad$ Marine Ecology 16:317-335. 
365 Forrester, G.E., M.A. Ferguson, C.E. O'Connell-Rodwell and L.L. Jarecki. 2014. Long-term survival 366 and colony growth of Acropora palmata fragments transplanted by volunteers for restoration. 367 Aquatic Conservation: Marine and Freshwater Ecosystems 24:81-91.

368 Forrester, G.E., A. Maynard, S. Schofield and K. Taylor. 2012. Evaluating Causes of Transplant Stress in Fragments of Acropora Palmata Used for Coral Reef Restoration. Bulletin of Marine

Forrester, G.E., O'Connell-Rodwell, C., Baily, P., Forrester, L. M., Giovannini, S., Harmon, L., Karis, Science 88:1099-1113.

374 Garrison, V. and G. Ward. 2008. Storm-generated coral fragments - A viable source of transplants 375 for reef rehabilitation. Biological Conservation 141:3089-3100.

376 Goreau, T.F. 1959. The ecology of Jamaican coral reefs: Species composition and Zonation. Ecology 40:67-90.

Griffin, S., H. Spathias, T.D. Moore, I. Baums and B.A. Griffin. 2012. Scaling up Acropora nurseries

Guest, J.R., R.M. Dizon, A.J. Edwards, C. Franco and E.D. Gomez. 2011. How Quickly do Fragments of Coral "Self-Attach" after Transplantation? Restoration Ecology 19:234-242.

383 Highsmith, R.C. 1982. Reproduction by Fragmentation in Corals. Marine Ecology Progress Series in the Caribbean and improving techniques Pages 1-5 in T.P. Hughes and D. Yellowlees (eds), 12th International Coral Reef Symposium. James Cook University. 
Johnson, M.E., C. Lustic, Bartels, I.B. Baums, D.S. Gilliam, L. Larson, et al. 2011. Caribbean Acropora Restoration Guide: Best Practices for Propagation and Population Enhancement. Arlington, VA: The Nature Conservancy.

390 Johnston, L. and M.W. Miller. 2014. Negative indirect effects of neighbors on imperiled scleractinian corals. Coral reefs 33:1047-1056.

392 Kiel, C., B. Huntington and M. Miller. 2012. Tractable field metrics for restoration and recovery monitoring of staghorn coral Acropora cervicornis. Endangered Species Research 19:171-

Kleinbaum, D.G. and M. Klein. 2011. Survival Analysis: A Self-Learning Text, Third Edition. New York: Springer.

Knowlton, N., J.C. Lang, M.C. Rooney and P. Clifford. 1981. Evidence for delayed mortality in 176.

Kumar, P. 2010. The economics of ecosystems and biodiversity—ecological and economic foundations. London.: Earthscan, p. 456.

401 Lee, E.T. 1992. Statistical Methods for Survival Data Analysis. New York: John Wiley \& Sons, Inc.

402 Lewis, R.R. 2009. Methods and criteria for successful mangrove restoration. Pages 787-798 in 403 G.M.E. Perillo (ed), Coastal wetlands : an integrated ecosystem approach. Amsterdam, Netherlands: Elsevier.

Lindahl, U. 1998. Low-tech rehabilitation of degraded coral reefs through transplantation of staghorn corals. Ambio 27:645-650.

Lindahl, U. 2003. Coral reef rehabilitation through transplantation of staghorn corals: effects of artificial stabilization and mechanical damages. Coral reefs 22:217-223. 
409 Lirman, D., S. Schopmeyer, V. Galvan, C. Drury, A.C. Baker and I.B. Baums. 2014. Growth

410 dynamics of the threatened Caribbean staghorn coral Acropora cervicornis: Influence of host

411 genotype, symbiont identity, colony size, and environmental setting. Plos One 9:9.

412 Mercado-Molina, A.E., C.P. Ruiz-Diaz and A.M. Sabat. 2014. Survival, growth, and branch

413 production of unattached fragments of the threatened hermatypic coral Acropora cervicornis.

$414 \quad$ Journal of Experimental Marine Biology and Ecology 457:215-219.

415 Merolla, S.A., A.J. Holevoet, S.L. Musser and G.E. Forrester. 2013. Caribbean Damselfish

416 Recolonize Reefs Following Coral Restoration. Ecological Restoration 31:353-356.

417 Miller, M.W., C. Marmet, C.M. Cameron and D.E. Williams. 2014. Prevalence, consequences, and

418 mitigation of fireworm predation on endangered staghorn coral. Marine Ecology Progress

$419 \quad$ Series 516:187-194.

420 Mumby, P.J. and R.S. Steneck. 2008. Coral reef management and conservation in light of rapidly

421 evolving ecological paradigms. Trends in Ecology and Evolution 23:555-563.

422 National Marine Fisheries Service. 2006. Endangered and threatened species: final listing

423 determinations for elkhorn coral and staghorn coral. Federal Register 71:26852-26872.

424 Paling, E.I., M. Fonseca, M. van Katwijk and M. van Keulen. 2009. Seagrass restoration. Pages 687-

425713 in G.M.E. Perillo (ed), Coastal wetlands : an integrated ecosystem approach.

426 Amsterdam, Netherlands: Elsevier.

427 Precht, W.F. 2006. Coral reef restoration handbook: the rehabilitation of an ecosystem under siege.

$428 \quad$ Boca Raton, FL: CRC Press.

429 Putz, F.E., G.M. Blate, K.H. Redford, R. Fimbel and J. Robinson. 2001. Tropical Forest Management

430 and Conservation of Biodiversity: An Overview. Conservation Biology 15:7-20. 
431 Rinkevich, B. 2005. Conservation of coral reefs through active restoration measures: Recent approaches and last decade progress. Environmental Science and Technology 39:4333-4342.

433 Rinkevich, B. 2014. Rebuilding coral reefs: does active reef restoration lead to sustainable reefs? 434 Current Opinion in Environmental Sustainability 7:28-36.

435 Rinkevich, B. 2015. Novel tradable instruments in the conservation of coral reefs, based on the coral 436 gardening concept for reef restoration. Journal of Environmental Management 162:199-205.

437 Schopmeyer, S.A., D. Lirman, E. Bartels, D.S. Gilliam, E.A. Goergen, S.P. Griffin, et al. 2017.

438 Regional restoration benchmarks for Acropora cervicornis. Coral reefs 36:1047-1057.

439 Shaish, L., G. Levy, G. Katzir and B. Rinkevich. 2010a. Coral Reef Restoration (Bolinao, $440 \quad$ Philippines) in the Face of Frequent Natural Catastrophes. Restoration Ecology 18:285-299.

441 Shaish, L., G. Levy, G. Katzir and B. Rinkevich. 2010b. Employing a highly fragmented, weedy coral 442 species in reef restoration. Ecological Engineering 36:1424-1432.

443 Shinn, E.A. 1966. Coral Growth-Rate, an Environmental Indicator. Journal of Paleontology 40:233$444 \quad 240$.

445 Smith, L.D. and T.P. Hughes. 1999. An experimental assessment of survival, re-attachment and 446 fecundity of coral fragments. Journal of Experimental Marine Biology and Ecology 235:147447164.

448 Spurgeon, J.P.G. 2001. Improving the economic effectiveness of coral reef restoration. Bulletin of 449 Marine Science 69:1031-1045.

450 ten Brink, P. 2011. The Economics of Ecosystems and Biodiversity in National and International 451 Policy Making. London and Washington: Earthscan. 
452 Toh, T.C., C.S.L. Ng, J.W.K. Peh, K. Ben Toh and L.M. Chou. 2014. Augmenting the Post-

453 Transplantation Growth and Survivorship of Juvenile Scleractinian Corals via Nutritional $454 \quad$ Enhancement. Plos One 9:9.

455 Tunnicliffe, V. 1981. Breakage and propagation of the stony coral Acropora cervicornis. Proceedings 456 Of The National Academy Of Sciences Of The United States Of America 78:2427-2431.

457 Yap, H.T. 2009. Local changes in community diversity after coral transplantation. Marine Ecology $458 \quad$ Progress Series 374:33-41.

459 Young, C.N., S.A. Schopmeyer and D. Lirman. 2012. A Review of Reef Restoration and Coral 460 Propagation Using the Threatened Genus Acropora in the Caribbean and Western Atlantic. $461 \quad$ Bulletin of Marine Science 88:1075-1098.

\section{Author affiliations and contact information}

464 Graham E. Forrester (corresponding author), Department of Natural Resources Science, University of 465 Rhode Island, 1 Greenhouse Road, Kingston, Rhode Island 02881, USA, gforrester@uri.edu

466 Maggie Chan, University of Alaska Fairbanks, College of Fisheries and Ocean Sciences, 17101 Point 467 Lena Loop Road, Juneau, Alaska.

468 Dennis Conetta, Department of Natural Resources Science, University of Rhode Island, 1 Greenhouse 469 Road, Kingston, Rhode Island.

470 Russell Dauksis, Department of Biology, California State University, Northridge, 18111 Nordhoff 471 Street, Northridge, CA.

472 Katie Nickles, Department of Biological Sciences, University of Rhode Island, 120 Flagg Road, 473 Kingston, Rhode Island. 
474 Alicia Siravo, Department of Biology, California State University, Northridge, 18111 Nordhoff

475 Street, Northridge, CA.

476

$477 \quad$ Figures

478 Figure. 1. Survival of coral fragments $( \pm 95 \% \mathrm{CI})$ in each of the experimental treatments: direct-

479 attached transplants, nursery outplants, and direct-loose transplants.

480 Figure. 2. Mean TLD ( $\pm 95 \%$ CI $)$ of surviving coral fragments over time in each of the experimental

481 treatments: directly attached transplants, nursery outplants, and direct-loose transplants.

482 Figure. 3. Return on investment, based on coral survival, for each experimental treatment. Absolute 483 survival at the end of the experiment is shown as a benchmark for comparison (top plot). Return on 484 investment is plotted as the number of survivors per hr invested (middle plot) and the number of 485 survivors per dollar invested (lower plot).

486 Figure. 4. Return on investment, based on the net production of coral tissue (TLD final $\left./ \mathrm{TLD}_{\text {initial }}\right)$, for 487 each experimental treatment. Raw means for net production at the end of the experiment are shown 488 as a benchmark for comparison (top plot). Return on investment is plotted as net production per hr 489 invested (middle plot) and net production per dollar invested (lower plot). 